\title{
Wisdom as outcome of the pastoral process: Reflections on a positive pastoral narrative approach
}

\author{
Author: \\ Alfred R. Brunsdon ${ }^{1}$ \\ Affiliation: \\ ${ }^{1}$ Department of Theology, \\ North-West University, \\ Mafikeng Campus, \\ South Africa \\ Correspondence to: \\ Alfred Brunsdon \\ Email: \\ alfred.brunsdon@nwu.ac.za \\ Postal address: \\ PO Box 10049, Lichtenburg \\ 2740 , South Africa \\ Dates: \\ Received: 14 Aug. 2014 \\ Accepted: 18 Feb. 2015 \\ Published: 30 Apr. 2015 \\ How to cite this article: \\ Brunsdon, A.R., 2015, \\ 'Wisdom as outcome of the \\ pastoral process: Reflections \\ on a positive pastoral \\ narrative approach', In die \\ Skriflig 49(3), Art. \#1873, \\ 8 pages. http://dx.doi. \\ org/10.4102/ids.v49i3.1873

\section{Copyright:} \\ C 2015. The Authors. \\ Licensee: AOSIS \\ OpenJournals. This work is \\ licensed under the Creative \\ Commons Attribution \\ License.
}

Read online:
From a South African perspective, pastoral care is typically concerned with the solving or resolving of critical issues such as marital crises or depression. It represents an approach that is based on a medical or disease model, addressing deficits rather than strengths in the lives of counselees. Therapeutic developments in the fields of the narrative approach and positive psychology have shifted the attention to the therapeutic nurturing of liberating stories and the strengthening of virtues. Thus, the quality of the human experience by capitalising on what is healthy and intact is enhanced. This article will explore the notion that the pastoral process should aim at understanding and nurturing emotional and spiritual strengths with wisdom as the outcome, rather than trying to unravel spiritual deficits as strategy for healing. Such a positive approach relies on wisdom as a foundational virtue. By cultivating wisdom, counselees become fit for a well-lived life. In light of this, the necessity for widening our traditional pastoral horizons is discussed. Scripture and positive psychology are considered as sources to inform the pastoral process on wisdom and the narrative is discussed as a means to uncover and cultivate wisdom in the lives of counselees. Markers for a positive pastoral narrative approach, aimed at the cultivation of wisdom, are suggested. This article endeavours to contribute to the enrichment of pastoral practitioners' frame of reference by drawing on the insights of neighbouring helping-disciplines, like the narrative and positive psychology employed within a practical theological paradigm, hence contributing to the ongoing call (semper reformanda) to always renew our theological endeavours.

Wysheid as uitkoms van die pastorale proses: Nadenke oor 'n positiewe pastoraalnarratiewe benadering. Vanuit ' $n$ Suid Afrikaanse perspektief is pastorale sorg tipies op die oplossing van probleme soos huwelikskonflik of depressie gerig. As sodanig verteenwoordig dit ' $n$ benadering wat op ' $n$ mediese of siektemodel gegrond is en op gebreke eerder as deugde van persone gerig is. Terapeutiese ontwikkelings op die terreine van die narratief en positiewe sielkunde het egter die aandag op die gebruik van bevrydende verhale en die versterking van deugde gevestig. Sodoende word die kwaliteit van die menslike bestaan verbeter deur voort te bou op dít wat gesond en ongeskonde in mense se lewens is. In hierdie artikel word die opvatting ondersoek dat die pastorale proses op die verstaan en kweek van geestelike en emosionele deugde gerig moet wees eerder as op die verstaan en ontknoping van probleme as strategie vir genesing - spesifiek met die deug van wysheid in gedagte. Só ' $n$ benadering berus op die aanname dat wysheid 'n deug is wat persone vir die lewe bemagtig. Die versterking van wysheid rus mense vir 'n vervulde lewe toe. In die lig hiervan word die noodsaaklikheid om bestaande pastorale verwysingsraamwerke te verbreed, bespreek. Die Skrif en die positiewe sielkunde word as bronne van kennis oor wysheid oorweeg en die narratief as 'n metode om wysheid in die lewens van die beradenes bloot te lê en verder te ontwikkel. Aanwysings vir 'n positiewe pastoraal-narratiewe benadering wat op die ontwikkeling van wysheid gemik is, word gegee. Die artikel poog om die verwysingsraamwerk van pastorale versorgers te verbreed deur binne 'n prakties-teologiese raamwerk uit die insigte van die positiewe sielkunde en die narratief te put. Op dié wyse word daarna gestreef om erns te maak van die oproep om voortdurend in die teologiese arbeid te vernuwe (semper reformanda).

\section{Prologue}

The broad theme for the In Luce Verbi Festschrift in honour of Prof. George Lotter, Pastoral Theology in South Africa: semper reformanda, struck me immediately as very appropriate. Through many years, Prof. Lotter has, to a large extent, embodied a spirit of semper reformanda in the field of Practical Theology in South Africa. My initial introduction to him happened largely due to his sincere curiosity about new developments in the field of practical theology. At a time when my own focus was on narrative pastoral care, Lotter contacted me, because he felt convinced that the narrative should be explored further within the reformed paradigm. Since then, he has become 
one of my mentors, a friend, co-author on a few occasions and a dear colleague. It is a privilege to contribute to this festschrift and I hope that this article $\mathrm{e}^{1}$ pays fitting tribute to his enduring embodiment of semper reformanda.

\section{Introductory remarks: Wisdom as outcome of the pastoral process?}

The introductory remarks to this article may be well served by simply formulating the first part of the title as a question: Wisdom as outcome of the pastoral process? The reason for this is that it would most probably be the reaction of many pastoral practitioners in South Africa, should they be informed that a 'virtue' such as wisdom should be the outcome of the pastoral process.

Underlying this question will be the frame of reference of pastoral practitioners who still view pastoral work within the framework of a disease model. From a psychological point of view, disease models focus on the treatment of deficits, rather than building on strengths (cf. Seligman \& Csikszentmihalyi 2000:6). When this view is applied to pastoral care, it represents the typical scenario, which still plays out in many, if not most, pastoral situations: counselees present the counsellor with a 'problem'; counsellors make an 'assessment' or 'diagnosis' and then take on the role of a 'problem solver', trying to remedy the 'problem' from a biblical, theological or pastoral perspective. Because of this disease model approach, a lot of pastoral energy is spent on building a good diagnostic framework in order to enable pastors to make accurate diagnoses of spiritual and social ills. Thus, knowledge on the strengthening of spiritual and personal strengths through which spiritual and social wellbeing can be promoted and nurtured, is being negated.

In this article, an attempt will be made to follow a 'positive' route, opposed to the disease model, by investigating one of the virtues of man, namely wisdom. More specifically, the positive relationship between wisdom and wellbeing, with the notion that wisdom can indeed contribute to our wellbeing, as it can be deemed as a foundational virtue - a virtue that enables a good life. In this manner, a pastoral approach that operates within the framework of a disease model is immediately challenged. Amongst others, the critical question arises whether a disease model would be able to accommodate the nurturing of virtues. Another question is whether a traditional approach to pastoral care has the vocabulary and some sort of strategy to promote a virtue like wisdom. There is good reason to believe that the answer to this would not be an outright 'yes'.

However, recognising wisdom as a virtue in the biblical and Christian tradition, and noting its prominence as a so-called foundational virtue in the field of positive psychology, it is the contention of this article that pastoral care can and must take on the challenge of contemplating a positive approach.

1.This article is a revised version of a paper that has been presented by the author a the annual conference of the British and Irish Association of Practical Theology on 17 July 2013 at the University of York in the United Kingdom.
In such a positive approach, the pastoral process should focus on the development of spiritual strengths or virtues in order to facilitate a more positive human experience.

\section{Epistemology and research method}

As this article intends to make a contribution to the field of pastoral care, it will operate within the epistemological paradigm of practical theology. The task of practical theology is to reflect critically on current practices in light of the Scriptures in order to promote growth in the praxis of the faith community (cf. Müller 2005:73; Osmer 2008:4).

This epistemological point of departure is also forming the basis of what pastoral care is believed to be, namely 'the expression and representation of the sensitivity and compassion of the Scripture's understanding and portrayal of God's encounter, intervention, interaction and involvement in our being human' (Louw 2010:73). 'God's [...] involvement in our being human' will, in the suggested positive approach to pastoral care, transcend mere problem solving and will include cultivating and nurturing the positive side of being human as God's children by facilitating a virtue such as wisdom during the pastoral process. It is this wisdom that will hopefully empower counselees to face their challenges and promote their wellbeing.

In this venture, the praxis of the pastoral process forms part of the investigation. Will a positive pastoral approach, for example, be limited to the pastor's consultation room? Will it be only informed by the Word of God and the Christian tradition? How wisdom will be cultivated through the pastoral process thus also falls in the scope of this article, as it will have to suggest some possibilities for the way in which this change is to be effected. It is in this regard that positive psychology and narrative therapy will be considered as approaches that can serve the pastoral process in an interdisciplinary methodology as vehicles to facilitate wisdom in the lives of counselees.

In order to investigate the research topic, the article will unfold as follows:

- Widening our pastoral horizons: from a disease model to a wellness-promoting model (positive pastoral care).

- Informing the pastoral process on wisdom: Scripture and positive psychology.

- Uncovering and cultivating wisdom in the lives of counselees: the narrative.

- Markers for a positive pastoral-narrative approach that is aimed at the cultivation of wisdom.

\section{Widening our pastoral horizons: from a disease model to a wellness- promoting model (positive pastoral care)}

As stated in the introduction, the author's observation of the pastoral practice in South Africa is that it still relies heavily 
on a disease model. In this approach, a lot of attention is paid to the identification, description and solving of the perceived problems of counselees. Symptomatic of this approach is the detailed attention that is devoted to the diagnosis of (pastoral) deficits (cf. Mack 1994:210-230). Pastoral diagnosis is, of course, not problematic in itself. Van Greunen (1997) points out that pastoral diagnosis is not primarily about labelling or classification, but rather about understanding and clarifying. It also forms part of the therapy. In this regard, the comprehensive contribution of Louw (2000:299-348), for example, provides for the recognition of healthy faith categories, which can be explored further. 'Diagnosis', however, still points to a pastoral approach, which finds its point of departure in the problems or weaknesses of people.

This approach is most probably rooted deeply in some of the dominant theological constructs that regulate our ministerial thinking and actions, for example.

\section{The pastoral tradition or heritage in which we stand}

In the past, South African pastors were mainly exposed to North-American, German and Dutch pastoral theologies. Our pastoral coordinates were plotted somewhere between Jay E. Adams (Nouthetic approach), Eduard Thurneysen (Kerygmatic approach) and Seward Hiltner (Eductive approach). ${ }^{2}$ Most of these approaches negated the positive side of counselees to a certain extent, focusing on their sins and seeing them as the 'object' of the kerygmatic action of the pastoral encounter, or as someone in need of the 'healing' and 'sustaining' that are partly provided by the pastor.

\section{Pastoral anthropology}

The phrase that summarises reformed anthropology best is arguably simul peccator et iustus [the notion that man is first of all a sinner, albeit justified through the grace of God]. This is a notion that has always seemed to dwell more on the meaning of sin than on the possibilities of justification.

\section{Ecclesiology}

For many years, one of the dominant metaphors for the church in the author's tradition, ${ }^{3}$ both in the minds of pastors and congregants, was the shepherd metaphor. In this metaphor, most of the attention falls on the pastor (shepherd) and his or her ability, instead of the abilities of the congregant. The body of Christ metaphor, which stresses the role (and possibilities) of the members of the church, has slowly replaced the shepherd metaphor, but not completely. In many of the rural communities, the shepherd metaphor is still the dominant construct of the church.

\footnotetext{
2.See Rossouw's Poimeniek Studiegids (1990), prescribed at the University of the (Orange) Free State and used at the seminary of the Dutch Reformed Church where the author received part of his theological training.

3.The author stands in the reformed tradition.
}

\section{Self-identity of the pastor}

Closely related to the ecclesiology is the self-identity of the pastor. To a great extent, pastors in the reformed tradition were trained to be the shepherds of the flock. A good example in this regard is the work of the late Prof. J.J. de Klerk, titled Herderkunde (1978), which means, directly translated, 'Sheperd -tology'. This reflects the paradigm for clerical work that was assimilated by many pastors. Strengthened by some classic Baxter (The Reformed Pastor 1656), a self-identity of a pietistic shepherd was formed which focused entirely on the abilities of the pastor who became the 'problem solver'.

These are but some of the constructs and discourses that encouraged a disease model approach in ministerial pastoral work, but now also serve as motivation for a widening of our pastoral horizons. If pastoral care should allow the counselee a proper voice in the healing process, our pastoral horizons need to widen. This widening should at least entail the following.

\section{Adjusting the pastoral lens from 'macro' to 'wide-angle'}

The above-mentioned analogy has two important implications. The obvious implication suggests that pastoral practitioners should embark consciously on a journey to rise above a problem paradigm. This journey could start with a critical enquiry into the pastoral relevance (Ganzevoort 2006) of our current practices in the local and global contexts. The contexts in which pastoral actions need to be embodied are in ever growing flux and necessitate 'stereoscopic' (cf. Bass \& Dykstra 2008:13) attention to changes in the way that people live and believe, focusing not just on the pathological, but also on the positive (Schoeman \& Van den Berg 2011:2). This implies taking an active interest in the activities of neighbouring sciences that are already exploring the positive, like the field of appreciative enquiry (Cooperrider, Whitney \& Stravos 2003:3) and positive psychology.

The other important implication of this analogy is that the macro function of the pastoral lens should remain and still be employed when need be (adjusting vs. switching). Widening our pastoral horizons does not mean an abandoning of existing frameworks altogether. Irrespective of the times that we live in, people will present with difficulties, which can be identified and described accurately within existing deficit frameworks. In contemplating alternative avenues, this should always be kept in mind.

\section{Taking pastoral care further than the consultation room}

A widening of our pastoral horizons also has implications for the space where pastoral care is dispensed. Although pastoral counselling will in all probability remain primarily associated 4.The 'macro' function of a camera lens refers to the ability to focus on the detail of
a photographic subject, excluding other elements of the scene, whereas the 'wide angle' function includes as much as possible of the scene. 
TABLE 1: A disease model versus a positive pastoral approach

\begin{tabular}{|c|c|}
\hline Disease model & Pastoral approach \\
\hline $\begin{array}{l}\text { A pastoral approach, based on the } \\
\text { disease model. }\end{array}$ & A positive pastoral approach. \\
\hline $\begin{array}{l}\text { Departs from 'below zero'a, } \\
\text { identifying deficits. }\end{array}$ & $\begin{array}{l}\text { Departs from 'above zero', identifying } \\
\text { strengths. }\end{array}$ \\
\hline Relies on knowledge about ills. & Relies on knowledge about virtues. \\
\hline Focuses on healing. & Focuses on enhancing and promoting. \\
\hline $\begin{array}{l}\text { Focuses on the pastoral encounter } \\
\text { (exclusive approach). }\end{array}$ & $\begin{array}{l}\text { Focuses on a more inclusive pastoral care, } \\
\text { integrated with other practical theological } \\
\text { disciplines for example homiletics and youth } \\
\text { work (inclusive approach). }\end{array}$ \\
\hline
\end{tabular}

with the pastoral setting of the consultation room, a positive approach can expand its possibilities outside this traditional setting. If the outcomes of the pastoral process become positive, surely other practical theological disciplines will come into consideration as vehicles for promoting these positive outcomes.

Here, the strategic roles of homiletics (positive pastoral preaching), youth programmes and small groups, to mention but a few, come to mind. These fields, not traditionally regarded as part of pastoral care, can most probably serve to build a frame of reference for foundational virtues such as wisdom. They can also serve as an extension of the positive counselling that is dispensed during the pastoral process. This frame of reference can be employed in a reciprocal (building further on it) manner if congregation members seek pastoral guidance in the pastor's consultation room.

The migration to a positive pastoral approach starts with a conscious widening of the pastoral horizon.

\section{A preliminary definition of positive pastoral care with wisdom as the outcome}

In light of the foregoing arguments, it is safe to continue from the premise that current pastoral praxis has room for the development of a positive approach. Apart from the writings of Ferreira (2010) as well as Schoeman and Van den Berg (2011), not much has emerged locally to stimulate thinking on a positive approach to pastoral care. It is still being positioned on the periphery of pastoral care in South Africa.

The author therefore wants to propose a preliminary scheme to serve as an indication of what a positive approach entails (see Table 1).

In this article, the positive approach is placed within the framework of wisdom as the imagined positive outcome. This means that the pastoral process will orientate itself in relation to wisdom. By facilitating and nurturing wisdom pastorally, it is believed that counselees will become fit for a meaningful life. ${ }^{5}$ This notion will now be further explored.

5 'Meaning ful life' as construct has special relevance in the field of positive psychology. Usually distinguishing between the 'pleasant', the 'good' and the 'meaningful life' 'meaningful life' points to applying one's signature strengths in the service of something larger than oneself (cf. Seligman 2002:249). In the Christian tradition 'something larger than oneself' becomes personified in God and the fellow man (cf. Lk 10:25-37).

\section{Informing the pastoral process on wisdom: Scripture and positive psychology}

In this part of the article, some attention will be given to two of the most obvious sources to inform the pastoral process on wisdom, namely the Scriptures and positive psychology. By saying 'most obvious', acknowledgement is given to the fact that there may be more sources of wisdom from which pastoral care can benefit, ${ }^{6}$ although only the Scriptures and positive psychology will be attended to in this article.

The purpose in this section is not to supply a comprehensive exegetical account of wisdom in Scripture and positive psychological literature, but rather to establish what wisdom entails and where or how it fits into a therapeutic framework or, simply put, where the pastoral counsellor would employ it.

\section{Wisdom in the Scriptures}

In both the Old and New Testament of the Scriptures, the socalled 'wisdom literature' is a well-known and acknowledged literary genre. In the Old Testament, it spans several books (or parts thereof), including Job, Proverbs, Ecclesiastes and certain psalms (Crenshaw 2009:42). Although less of a prominent genre in the New Testament, wisdom literature is also integrated in the New Testament text, most of the time in the form of sayings that were used by Jesus in the Gospels (Burkett 2002:176; Harvey 2004:48) and also as part of his teachings on the Kingdom of God, which links Jesus to the wisdom literature of old Israel (Harris 2012:295). The most prominent corpus of wisdom teachings that are ascribed to Jesus is arguably from the Sermon on the Mount (Mt 5-7), as found in the beatitudes in Matthews 5:3-12 (cf. Ferreira 2010:91). Another New Testament source of wisdom literature is also found in James, who has heavily relied on the book of Proverbs to inform his own teachings on wisdom (Achtemeier, Green \& Thompson 2001:501). ${ }^{7}$

In terms of theological intent, the wisdom writings in Scripture are aimed at making man fit for a life well lived as it dispenses advice on most of the human experience. Walton and Hill (2004:315) have proposed that certain wisdom literature pertains to certain fields of the human experience: in the Psalms, advice is given to man on his relationship with God; in Proverbs, on society and family; in Song of Songs, on love and sexuality; in Ecclesiastes, on the meaning of life; and in Job, on moral structure. Of relevance is the notion that the virtue of wisdom comes from God and he himself rewards those who seek it (cf. Viviers 2005). Not seeking wisdom amounts to foolishness, and gathering with the unwise (those who do not share in God's wisdom; see Ps 1:1) will lead to one's downfall.

6 . Consider in this regard some of the apocryphal literature or deuterocanonical books, for example The Wisdom of Solomon and Jesus Sirach (cf. Mijnhardt 1996).

7.See Achtemeier et al. (2001:501) for an elaborate comparison of James's teachings on wisdom in relation to the wisdom teachings that are found in the book of Proverbs. 
The more specific question about what this wisdom entails, seems to have a twofold answer. On the one hand, this question is answered in a direct manner in both the Bible and the Apocrypha. ${ }^{8}$ In Proverbs 1:7, Solomon states that 'fear of the Lord is the beginning of knowledge' (da'ath) and in chapter 9:10 this notion is repeated with a slight change in the word order, namely 'fear of the Lord is the beginning of wisdom' (chokmâh). At the end of Ecclesiastes (12:13), the imperative to fear God becomes the summary of a whole book of wisdom-teaching.

This 'fear of God,' however, needs to be understood in a correct manner. Derived from the Hebrew word yârê, 'fear' is used in a positive sense, namely to have a relationship with God. This relationship is a faith relationship based on trust and the recognition of God as the creator and keeper of people. This Old Testament fear comes into greater perspective when, in the New Testament, God becomes flesh in Jesus and wisdom becomes personified in the Son of God. In this regard, Paul writes in 1 Corinthians 1:30: 'But of him are ye in Christ Jesus who of God is made unto us wisdom, and righteousness, and sanctification, and redemption.' Jesus is now the sophia from God, and those coming into a relationship with him are coming into a relationship with wisdom; hence wisdom may be regarded as a relational concept. In this relationship, wisdom becomes a gift from the Holy Spirit (cf. Eph 1:17), which enables the believer to gain even more wisdom from the personified wisdom, Jesus Christ; which also gives wisdom a reciprocal character. It should be noted that this wisdom is accessible to all. According to James 1:5, wisdom is at the disposal of all who seek it from God: 'If any of you lack wisdom, let him ask of God, that giveth to all liberally, and upbraideth not; and it shall be given him.' The only prerequisite seems to be a willingness to accept God as the source of wisdom and the willingness to change in light of God's liberating wisdom (cf. Rm 12:1).

On the other hand, the question about what wisdom entails can also be answered in a very practical manner. Practical wisdom is found in the instructions and teachings of wisdom literature in the Bible. The content of these instructions and teachings is the embodiment of Scriptural wisdom, the physical information, which leads to the liberation of life on earth. Taking the aforementioned about the fear of God as wisdom into account, the whole revelation of God in the Scriptures could be regarded as the what of wisdom, but, in specific terms, the content of wisdom literature provides a clear frame of reference for wisdom. The goal of this practical wisdom is embodied in Browning's notion of phronesis (1991), which seeks answers to the questions of how we should live and what we must do as a form of applied practical wisdom. Indeed, wise people both listen to the message of Jesus and build their lives upon it (Browning 1991:10).

In part this answer also addresses the question of where or how wisdom fits into the therapeutic context. As already shown by the quote from the work of Walton and Hill (2004),

8.See Ben Sira 1:16 (Mijnhardt 1996). the content of the different bodies of wisdom literature will be suitable for application in different pastoral settings. In a recent doctoral thesis on wisdom as an executive virtue for positive psychology, Ferreira (2010) has also shown that the instructions and teachings that are found in wisdom literature can be applied to various areas of life (and pastoral situations). Amongst other, this wisdom literature provides structure to the lives of its pupils, give guidelines for a just life, order, love and a realistic outlook on life (Ferreira 2010:62-69), making it applicable to a whole array of pastoral challenges.

The challenge for the pastor will be to develop a grounded frame of reference from the instructions and teachings that are found in the wisdom literature, which will be applicable within different pastoral scenarios such as marriage counselling and conflict management family therapy. The challenge will also be to develop the theme of wisdom for pastoral use in the broader sense of the word (as previously mentioned), namely for pastoral preaching, youth work, et cetera.

\section{Wisdom in positive psychology}

A secondary source that informs pastoral care about wisdom is positive psychology. Unfortunately, a detailed account of the history of this branch of psychology falls outside the scope of this article. However, most scholars who are involved in the helping disciplines took note of this new direction in psychology after the watershed plea of Martin Seligman in 1998 that traditional psychology should shift its attention away from the disease model and replace it with the quest of understanding happiness and thriving, establishing the building blocks of a meaningful life and how we can promote it (Seligman \& Csikszentmihalyi 2000:6).

Since then, psychologists started to invest time in research about the positive side of human behaviour, trying to understand and describe the life above zero. ${ }^{9}$ According to Baumgardner and Crothers (2010), this resulted in the:

scientific study of the personal qualities, life choices, life circumstances and sociocultural conditions that promotes a life well-lived, defined by criteria of happiness, physical and mental health, meaningfulness and virtue. (p. 9)

The human virtue of wisdom also falls in the scope of these scientific studies. To the best of the author's knowledge, no other field of science has recently made the same effort to describe and comprehend wisdom in the way positive psychology has done over the last decade, making positive psychology an important partner for dialogue in our need to understand the possibilities of wisdom as a therapeutic outcome.

What immediately attracts one's attention about wisdom in the positive psychological context is the prominence it has

9.Baumgardner and Crothers (2010:9) see "zero' as the line that divides illness from health and unhappiness from happiness. In studying life above zero, we are trying health and unhappiness from happiness. In studying life above zero, we are trying to learn more about a life where unhappiness and illness are
life that could also be described as happy and meaningful. 
been awarded in achieving a meaningful life. Generally denoted as a foundational or executive virtue (Ferreira 2010), it is regarded as inadmissible in the formation of a meaningful life. In a classification of virtue and character strengths, compiled by Seligman, Steen, Park and Peterson (cf. Baumgardner \& Crothers 2010:210), wisdom tops the hierarchy of virtues. According to the compilers, wisdom is founded on the character strengths of creativity, curiosity, open-mindedness, love of learning and perspective. The more these character strengths grow, the more a person will grow in terms of wisdom. However, despite the fact that wisdom may be stimulated by curiosity and a love of learning, wisdom is not to be understood as mere theoretical knowledge. Rather, wisdom has to do with a philosophic understanding of what really matters in life as well as the practical knowledge of how to conduct a life that 'matters' (cf. Baumgardner \& Crothers 2010:213).

Apart from contributing valuable knowledge towards an understanding of the constituents of wisdom, theorists are also paying attention to practical wisdom, in other words, putting wisdom theory into practice in order to attain a meaningful life. One example is the SOC Model of Effective Life Management that has been developed by Baltes and colleagues (Baumgardner \& Crothers 2010:218). The SOC acronym refers to selection, optimisation and compensation, which denote a dynamic process of deciding which goals are the most appropriate to a purposeful life (selection). It combines choices and actions, and monitors the progress towards the attainment of goals (optimisation) and the ability to find or develop alternative channels to achieve goals when previously chosen paths are blocked (compensation).

In light of these few remarks on the description of wisdom in positive psychology, it should be clear that positive psychology is a valuable partner in the pastoral quest to comprehensively understand wisdom as a foundational virtue. Of specific value for a pastoral meta-theoretical enquiry is the scientific description of wisdom as a phenomenon and how it fits into human experience, showing that it is indeed one of the driving forces of a meaningful life. Another valuable contribution is the systematic identification of the strengths that underlie wisdom. This unlocks more possibilities for a comprehensive approach to develop the virtue of wisdom, for instance by stimulating the curiosity and creativity of counselees. Lastly, positive psychology also provides a framework for evaluating (measuring) the level of wisdom in the lives of counselees.

\section{Uncovering and cultivating wisdom in the lives of counselees: The narrative}

The focus of this article now turns to the domain of praxis, specifically the question regarding which therapeutic framework would be suited for the facilitation of wisdom. To the author's mind, a narrative approach, which relies on the co-constructing of preferred realities (Freedman \& Combs 1996), can serve the purpose. By proposing a narrative approach, other possibilities such as appreciative enquiry (cf. Cooperrider et al. 2003) are not disqualified; the narrative serves as an example of a facilitative approach.

The narrative approach, pioneered by White and Epston (1990), was well-received in South Africa in the early 1990s. However, it created quite an epistemological debate, as it operated from a postmodern paradigm in which constructs like grand narratives and truth become relative (cf. Janse van Rensburg 2000). In a reformed context, the use of the narrative was under epistemological suspicion. The answer to this was a hybrid-narrative approach where strategies of the narrative were employed without buying into a postmodern paradigm. Qualified as a pastoral-narrative approach, the authority of Scripture could be maintained (cf. Brunsdon \& Janse van Rensburg 2008).

In a pastoral process that aims at the outcome of wisdom, the narrative approach has much potential. At the core of the proposed pastoral process lies the uncovering of existing wisdom in the lives of counselees on which further building can proceed. Working with the story analogy, the narrative is serious about the stories which constitute the life-stories of people. It is an unobtrusive way of discovering where people are, whether in a good or bad place. It not only uncovers the problem-saturated stories, but exposes the unique outcomes on which the pastoral process can respond in a positive way. It 'pans for gold' (cf. Wylie 1994), which can serve as the linking-up point for the pastor as the coauthor or journey partner. In this case, it will be especially sensitive for unique outcomes where counselees have acted 'wisely'. From here, the narrative of the counselee can be merged with the grand narrative of Scripture, and relevant constructs from the wisdom genre can be employed to enrich and inform the counselee's own narrative in the quest for wise living, leading to a positive experience of being human.

\section{Markers for a positive pastoral approach with wisdom as the outcome}

In conclusion, a few markers are envisaged for a positive pastoral approach with wisdom as the outcome. This is done in a cursory fashion in order to give some indication of how this approach can be employed.

\section{Widening the pastoral horizons of counselees}

Bearing the South African context in mind, migrating to a positive approach in pastoral care once again implies adjusting the frame of reference of counselees. To put it bluntly: the disease model and the shepherd metaphor made congregation members lazy in terms of the management of pastoral problems. For many years, the adage, 'go to the pastor, he or she will know,' applied. In a positive approach, the focus is shifted to the wisdom within as well as finding 
or learning the wisdom that God put at our disposal as source for positive pastoral care. Changing public discourses in the changing zeitgeist has helped a lot in changing the perceptions of people in terms of their own worth and strengths as well as the importance of their own narratives when it comes to change, but many still have to widen their perceptions.

\section{Creating a 'wisdom' frame of reference}

Counselees need to be introduced to a pastoral process in which wisdom becomes the desired outcome. An understanding of wisdom as a foundational virtue that can transform our lives in light of God's wisdom as seen in Christ, bring order to our lives and provide practical parameters for life, needs to be developed. This understanding needs to be cultivated by relating the Bible's teachings on wisdom as well as the findings of positive psychology to the lives of counselees. If wisdom also features within the congregation through preaching, teaching and modelling, relating wisdom to the personal lives of counselees stands on firmer ground. The most important principle in creating this frame of reference remains the fact that wisdom, in biblical terms, is a relational concept, for real wisdom is to be sought in the sophia from God, namely Jesus Christ. Once the counsellor lead the counselee to acknowledge and recognise Christ as such, the pastoral process can proceed.

\section{Panning for gold}

By engaging with the narratives of counselees, unique outcomes can be sought where wisdom has played a role in the management of their lives, or they may have to face up to the fact that up to now, their life-stories show weak or no utilisation of wisdom. The wisdom narratives of Scripture also need to be panned in order to discover wisdom that enables positive living. The possibilities here are many, for example Bible readings or studying wisdom literature to facilitate a true discovery of the liberating wisdom of God's Word. It is important for counselees to realise from the start that wisdom does not function in a mechanical way (e.g. that living 'according to the book of Proverbs' will ensure a good outcome), but that it is about lives that are changed by thinking anew (cf. Rm 12:1).

\section{Solidifying the stories of wisdom - being human - being wise}

A positive approach to pastoral care is most probably an open-ended one. It does not 'end' at the discovery of wisdom or even at the attempts of counselees to live wisely. The new stories they live according to the wisdom principles of the Bible and in relation to God's sophia need to be visited and revisited in order to discover how wisdom liberates life. New narratives, which were built on the practical wisdom of the Bible, need to be deconstructed in order to be understood for counselees to be motivated to live wisely in a sustainable manner. It needs to be solidified, building a strong foundation that can serve for the narratives that are yet to be constructed.

\section{Conclusion}

This article has attempted to build a bridge from a disease model to a positive model for pastoral care with wisdom as the outcome. It was constructed against the perceived South African ministerial pastoral practice. It has shown that a positive approach, driven by wisdom literature from Scripture and the meta-theoretical insights of established positive psychology, has the potential of liberating and structuring the lives of counselees. The narrative approach to therapy has been suggested as one way of putting a positive approach into practice. Although limited by the lack of specific exegesis of wisdom literature or a case study, the approach shows potential and can be explored further as a means of ongoing renewal (semper reformanda) of pastoral theology.

\section{Acknowledgements Competing interests}

The author declares that he has no financial or personal relationship(s) that may have inappropriately influenced him in writing this article.

\section{References}

Achtemeier, P.J., Green, J.B. \& Thompson, M.M., 2001, Introducing the New Testament: Its literature and theology, Eerdmans, Grand Rapids.

Bass, D.C. \& Dykstra, C., 2008, For life abundant: Practical theology, theological education and Christian ministry, Eerdmans, Grand Rapids.

Baumgardner, S.R. \& Crothers, M.K., 2010, Positive psychology, Pearson, Upper Saddle River.

Baxter, R., [1656] 1989, The Reformed pastor, BPCC Hazell Books Ltd., Aylesbury.

Browning, D., 1991, A fundamental practical theology: Descriptive and strategic proposals, Fortress Press, Minneapolis.

Brunsdon, A.R. \& Janse van Rensburg, J., 2008, 'Cancer in retirement: A narrative approach', NGTT 49(3 \& 4) Sep. \& Dec., 25-39.

Burkett, D., 2002, An introduction to the New Testament and origins of Christianity Cambridge University Press, Cambridge.

Cooperrider, D.L., Whitney, D. \& Stravos, J.M., 2003, Appreciative inquiry handbook: The first in a series of Al workbooks for leaders of change, Berret-Koehler Publishers, San Francisco.

Crenshaw, J.L., 2009, 'Sipping from the cup of wisdom', in P.K. Moser (ed.), Jesus and philosophy, pp. 41-62, Cambridge University Press, Cambridge.

De Klerk, J.J., 1978, Herderkunde, NG Kerkboekhandel, Goodwood.

Ferreira, J.L., 2010, 'Practical wisdom as executive virtue for positive psychology: A pastoral-theological evaluation', PhD thesis, Faculty of Theology, NWU, Potchefstroom Campus.

Freedman, J. \& Combs, G., 1996, Narrative therapy: The social construction of preferred realities, W.W. Norton, New York.

Ganzevoort, R.R., 2006, De hand van God en ander verhalen: Over veelkleurige vroomheid en botsende beelden, Uitegeverij Meinema, Zoetermeer.

Harris, S.L., 2012, The New Testament: A student's introduction, 7th edn., McGrawHill, New York.

Harvey, A.E., 2004, A companion to the New Testament, 2nd edn., Cambridge University Press, Cambridge. http://dx.doi.org/10.1017/CBO9780511811371

Janse van Rensburg, J., 2000, The paradigm shift, J.L. van Schaik, Pretoria.

Louw, D.J., 2000, A pastoral hermeneutics of care and encounter, Lux Verbi BM, Wellington.

Louw, D.J., 2010, "Care to the human "soul" in contemporary theological formation From "kerymatics" to "fortigenetics" in pastoral anthropology', NGTT 51(3\&4), 70-81.

Mack, W.A., 1994, 'Taking counselee inventory: Collecting data', in J.F. MacArthur \& W.A. Mack (eds.) Introduction to Biblical counselling: A basic guide to the principles and practice of counselling, pp. 210-230, Word, Dallas.

Mijnhardt, F., 1996, Apokriewe van die Ou Testament, J.L. van Schaik, Pretoria.

Müller, J., 2005, 'A postfoundationalist, HIV-positive practical theology', Praktiese Teologie in Suid-Afrika 20(2), 72-88.

Osmer, R.R., 2008, Practical theology: An introduction, Eerdmans, Grand Rapids. 
Rossouw, P.J., 1990, Poimeniek: Studiegids, University of the Orange Free State, Bloemfontein.

Schoeman, K. \& Van den Berg, J.A., 2011, 'An appreciation for the positive! Appreciative engagement as congregational process and congregational and pastoral lens', HTS Teologiese studies/HTS Theological studies 67(2), Art. \#887, 7 pages.

Seligman, M.E.P., 2002, Authentic happiness: Using the new positive psychology to realize your potential for lasting fulfilment, Free Press, New York.

Seligman, M.E.P. \& Csikszentmihalyi, M., 2000, 'Positive psychology: An introduction' American Psychologist 55(1), 5-14. http://dx.doi.org/10.1037/0003-066X.55.1.5
Van Greunen, A.J., 1997, 'Pastorale diagnose en hipotesevorming in die pastorale gesprek:'n Bespreking', MA thesis, Faculty of Theology, University of Stellenbosch. Viviers, H., 2005, 'The "body" and Lady Wisdom (Proverbs 1-9)', OTE 18(3), 879-890. Walton, J.H. \& Hill, A.E., 2004, Old Testament today: A journey from original meaning to contemporary significance, Zondervan, Grand Rapids.

White, M. \& Epston, D., 1990, Narrative means to therapeutic ends, W.W. Norton, New York.

Wylie, M.S., 1994, 'Panning for Gold', Family Therapy Networker 18(6), November/ December, 40-48. 